\title{
Determining Components That Are Strongly Correlated To Rural Community Interest And Willing In Using And Utilizing Mobile Money In Tasikmalaya District
}

\author{
Edi Sukmadirana (Corresponding author) \\ Management and Business, IPB University \\ PO box 16128, Jl. Raya Pajajaran, RT.03/RW.06, Bogor, Indonesia \\ Tel: +628159630506 E-mail: edisukma2016@gmail.com \\ Kudang Boro Seminar \\ IPB University \\ PO box 16128, Jl. Raya Pajajaran, RT.03/RW.06, Bogor, Indonesia \\ Tel: + 628164834625 E-mail: seminarkudangboro@gmail.com \\ Muhammad Firdaus \\ IPB University \\ PO box 16128, Jl. Raya Pajajaran, RT.03/RW.06, Bogor, Indonesia \\ Tel: +628129291996 E-mail: mfirdaus@ipb.ac.id, firdausfemipb@yahoo.com \\ Yandra Arkeman \\ IPB University \\ PO box 16128, Jl. Raya Pajajaran, RT.03/RW.06, Bogor, Indonesia \\ Tel: + 628121114359 E-mail: yandra_ipb@yahoo.com
}

\begin{abstract}
The development of the application of mobile money in rural communities is a strategic step to increase the financial literacy of rural communities, thus supporting the development of agribusiness in rural areas. In its development, it must be supported by a structured disimenation design and adapted to the conditions and capabilities of rural communities. This research was conducted in Tasikmalaya District in three sub-districts, namely: Singaparna, Rajapolah, and Ciawi, using secondary data and primary data through questionnaires to 207 respondents. The dissemination design model built refers to the Theory of Technology Acceptance Model (TAM) (Davis 1989), the four-factor dissemination model (Cummings and Teng 2003), and the knowledge dissemination model (Vito Albino et al. 1998), which consists of 6 components, namely: Activity, Media, Perceived Usefulness, Perceived Ease of Use, Behavioural Intention and Usage Behaviour, by using descriptive data analysis and Structural Equation Modeling (SEM). These six components are proven to have a strong correlation with the intention and willing behaviour of rural communities in using and utilizing mobile money. The indicators that have a strong correlation with each component are: infrastructure, regulations, social media, electronic media, product value, product discounts, capability and public awareness. The process of disseminating the application of mobile money technology in rural communities is correlated with infrastructure readiness, community capacity, regulations, appropriate product value, attractive prices and periodically delivering updated information to the public through social media.
\end{abstract}

Keywords: Dissemination, Mobile Money, Rural, Structural Equation Modeling (SEM).

DOI: $10.7176 / \mathrm{EJBM} / 12-30-09$

Publication date:October $31^{\text {st }} 2020$

\section{Background}

Mobile money technology is growing vary fast in line with the development of online businesses that offer convenience and speed in the payment system. Currently, the mobile money payment system has been widely used 
in various business transactions in urban communities. The government continues to encourage the expansion of the digitization of non-cash payments in various business areas to support the sustainable economic growth. The government's challenges in expanding the application of mobile money include: changing the landscape of the national payment system, strengthening the non-cash payment ecosystem and the availability of currency fit for circulation throughout Indonesia.

Based on data from Bank Indonesia, non-cash payment transactions in Indonesia have increased over the past decade, as shown in Figure 1.

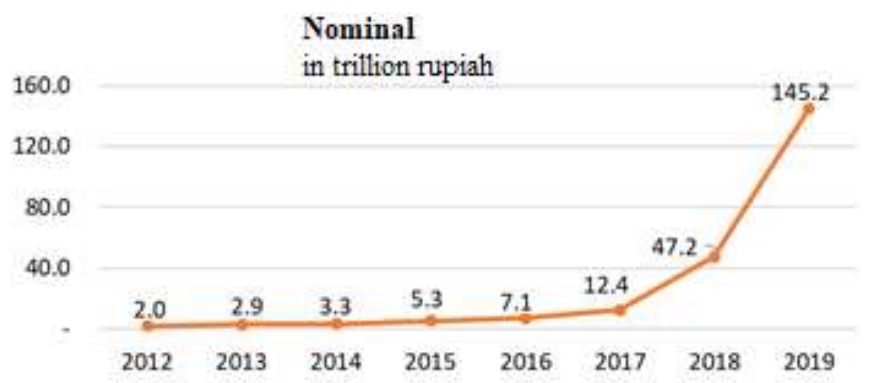

Figure 1. Nominal non-cash transactions in Indonesia, 2013-2019

Source: Bank Indonesia (2020), compiled

A high increase occurred in 2018 to 2019 and was more dominant in urban communities, especially for transactions in the retail sector such as: minimarkets, merchants, Transjakarta, Commuter Line, campus / school canteens, toll payments, parking payments, on-line motorcycle taxi transportation and Smart Card. The application of mobile money needs to be developed in rural communities, so that it is expected to improve the welfare of rural communities.

The development of mobile money application in rural communities is a strategic step to increase financial literacy, agribusiness development and increasing the welfare of rural communities. This development must be supported by a structured dissemination design, adapted to the conditions and capacities of rural communities. The process of dissemination is often neglected in planning the development of a product by business actors, even though the process of dissemination is the key to the success of the continued use of a product, especially mobile money products are developing very fast, demanding an effective, efficient and integrated dissemination model. This study is conducted to determine which components have a strong correlation to the dissemination process of mobile money in rural communities, especially in Tasikmalaya District.

\section{Literature Review}

\subsection{Dissemination}

Dissemination means to spread or to distribute (Hornby 1974; Echols and Shadily 1997), which is the process and rate of exchange of knowledge through one entity to another (Hari 1994; Kohli et al.1993). Measuring changes in knowledge embedded in individuals, through three dimensions, namely: understanding (Zahra et al 2000), usability (Simonin 1999; 2004), and speed (Zahra et al 2000; Zander and Kogut 1995). In the process of implementing a communication and dissemination strategy, the steps that need to be taken are: determining objectives, identifying core messages, target audience, media, frequency and impact (Cees Leeuwis 2006).

Dissemination is an act of innovation activities that are compiled and disseminated with careful planning, aimed at target groups or individuals, so that they get information, raise awareness, accept, and finally make use that information. In the dissemination process, it is necessary to identify stakeholders, either groups or individuals who can influence or be affected in achieving goals, then map them into awareness categories, understanding categories, and action categories (Harmsworth S and Turpin S 2000).

\subsection{Mobile Money}

The use of mobile money can increase people to save, borrow, receive and send money (Munyegera and Matsumoto 2015). Through the application of the transformation of traditional dissemination to modern dissemination with the use of information and communication technology (ICT) will strengthen the acceleration of the process of transferring agricultural knowledge and technology to farmers (Ankur Kukrej and Bidisha Chakrabarti 2013). Creating a good relationship between source and recipient will speed up the process of knowledge transfer (Nonaka 1996; Szulanski 1996). 


\section{Research Method}

The components used in this study refer to the Theory of Technology Acceptance Model (TAM) which explains simply the user acceptance reaction to technology based on two factors, namely perceived usefulness and perceived ease of use (Davis 1989). Other components that influence these two factors refer to the four-factor dissemination model, namely: sources, recipients, media and activities (Cummings and Teng 2003) and a knowledge dissemination model consisting of: actors, context, content and media (Vito Albino et al. 1998). Based on this theoretical reference, in this study, the component correlation configuration model built in the mobile money dissemination process for rural communities in Tasikmalaya District such as Figure 2.

The data used in this study include primary data and secondary data. Secondary data are collected through literature studies, the Central Bureau of Statistics (BPS), mobile money providers, telecommunications providers / operators, banking and Bank Indonesia. Primary data collection through questionnaires and in-depth interviews with 207 rural communities randomly sampled who live in Tasikmalaya District in three sub-districts, namely: Singaparna, Rajapolah, and Ciawi.

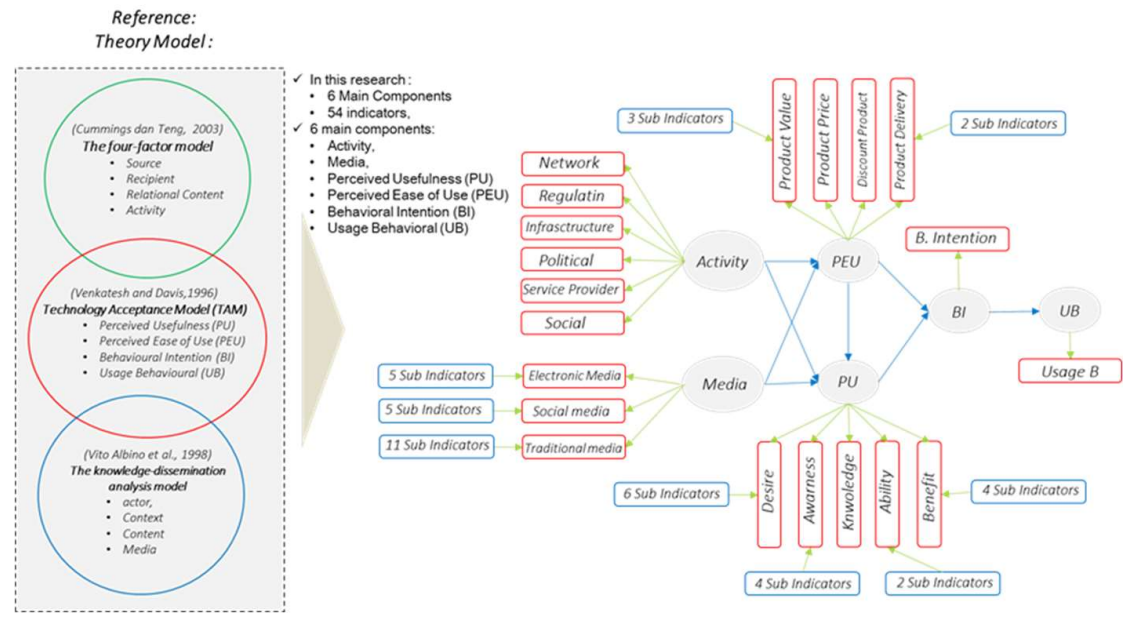

Figure 2. Dissemination component correlation configuration model

Data analysis tools used in this research are descriptive analysis and Structural Equation Modeling (SEM). Each main component is translated into relevant indicators, which are listed in the questionnaire. The format of the questionnaire is arranged using a Likert scale, which is a scale that makes respondents to determine the level of agreement and disagreement of each statement in the questionnaire which is stated on a scale of one to five (Malhotra 2007).

The data analysis technique uses the Structural Equation Modeling (SEM), to thoroughly explain the relationship between the indicators in the study. SEM is used not to design a theory, but rather to examine and justify a model. Therefore, the main requirement for using SEM is to build a hypothetical model consisting of a structural model and a measurement model in the form of a path diagram based on theoretical justification. With SEM, the researchers can carry out three activities at once, namely checking the validity and reliability, testing the relationship model between latent variables, and getting a model that is useful for prediction (Yamin 2009).

\section{Research Result}

\subsection{Respondent Profile}

Descriptive analysis is conducted to describe and determine the relationship between components and indicators by looking at the type of respondent and level of education. The types of respondents in this study are divided into four clusters consisting of Learners / Students, PNS / POLRI / TNI / Private Employees, Entrepreneurs / Traders and Farmers / Laborers. The amount of data used in processing using survey data with the number of respondent data is 207 respondents. The data are processed using SPSS software with the results of processed data can be seen in Table 1 and Table 2.

In this study, interviews are conducted with 207 respondents with different background clusters, occupations and education. Based on the clusters in Table 1, the results of the analysis show that the respondents come from Farmer / Labor clusters (71 people) and the least clusters are Learner / Student clusters (as many as 41 people). 
Table 1. Respondents based on occupation clusters

\begin{tabular}{lcc}
\hline Cluster & Frequency & Percent \\
\hline Student & 41 & 19.33 \\
PNS / TNI / POLRI / Private Employee & 45 & 21.73 \\
Trader / Entrepreneur & 50 & 24.15 \\
Farmer / Laborer & 71 & 34.29 \\
\hline Total & 207 & 100.0 \\
\hline
\end{tabular}

Based on the education level category, it is known that the most respondents come from SLTA graduates, namely 84 respondents, S1 as many as 66 respondents, SLTP as many as 49 respondents, and S2 / S3 as many as 8 respondents. Full results can be seen in Table 2 .

Table 2. Respondents based on education

\begin{tabular}{ccc}
\hline Education & Frequency & Percent \\
\hline SLTP & 49 & 23.67 \\
SLTA & 84 & 40.57 \\
S1 & 66 & 31.88 \\
S2/S3 & 8 & 3.86 \\
\hline Total & 207 & 100.0 \\
\hline
\end{tabular}

\subsection{Structural Equation Modeling (SEM) Model Analysis}

In this study, as a whole, it consists of 6 main components and 54 indicators. The main components in the research consist of: Activities, Media, Perceived Usefulness, Perceived Ease of Use, Behavioural Intention, and Usage Behaviour. The exogenous latent component of Activities is reflected by six indicators, namely Regulation, Infrastructure, Service Provider, Social, Political and Network. The latent component of Perceived Usefulness is described by five indicators, namely Awareness (4 sub-indicators), Desire (6 sub-indicators), Knowledge, Ability (2 sub-indicators), and Perceived Usefulness (4 sub-indicators). Perceived Ease of Use is reflected by four indicators, namely Product Value (3 sub-indicators), Product Price, Product Discounts, and Product Delivery (2 sub-indicators). Media is described by three indicators, namely Social Media (5 sub-indicators), Electronic Media ( 5 sub-indicators), and Traditional Media (11 sub-indicators). Behaviour Intention is described by one indicator, namely the consistency of the respondents towards the use of mobile money. Meawhile, Usage Behaviour is reflected by one indicator, namely the behaviour of the respondent in using the mobile money in everyday life.

From the conceptual model, the hypothesis developed in this study is:

H1: Activity has a direct positive correlation to Perceived Ease of Use.

H2: Activity has a direct positive correlation to Perceived Usefulness.

H3: Media has a direct positive correlation to Perceived Ease of Use.

H4: Perceived Ease of Use has a direct correlation to Perceived Usefulness.

H5: Perceived Usefulness has a direct correlation to Behaviour Intention.

H6: Behaviour Intention has a direct correlation to Usage Behaviour.

Table 3. Cut-off guidelines for interpretation of test results

\begin{tabular}{|l|l|l|l|l|}
\hline \multicolumn{2}{|l|}{ Type of Testing } & \multicolumn{1}{|c|}{ Criteria } & Cut-off Value & \\
\hline \multicolumn{2}{|c|}{ Measurement Model Analysis } \\
\hline 1. & Validity Test & $\begin{array}{l}\text { Standardized Loading Factor (SLF) } \\
\text { t-value }\end{array}$ & $\geq 0.50$ & Valid \\
& & & $\geq 1.96$ & Valid / Significant \\
\hline 2. & Goodness of Fit Test & p-value of $\chi^{2}$ & $\geq 0.05$ & Good Fit \\
& RMSEA & $\leq 0.08$ & Good Fit \\
& NFI & GNFI & $\geq 0.90$ & Good Fit \\
& RFI & $\geq 0.90$ & Good Fit \\
& CFI & $\geq 0.90$ & Good Fit \\
& GFI & $\leq 0.90$ & Good Fit \\
& & Standardized RMR & $\geq 0.05$ & Good Fit \\
& GFI & Good Fit \\
\hline
\end{tabular}




\begin{tabular}{|c|c|c|c|c|}
\hline & Type of Testing & Criteria & Cut-off Value & Notes \\
\hline & & AGFI & $\geq 0.90$ & Good Fit \\
\hline 3. & Reliability Test & $\begin{array}{l}\text { Construct Reliability (CR) } \\
\text { Variance Extracted (VE) }\end{array}$ & $\begin{array}{l}\geq 0.70 \\
\geq 0.50\end{array}$ & $\begin{array}{l}\text { Good Reliability } \\
\text { Good Reliability }\end{array}$ \\
\hline \multicolumn{5}{|c|}{ Structural Model Analysis } \\
\hline 1. & Goodness of Fit Test & Same as above & & \\
\hline 2. & $\begin{array}{l}\text { Combined } \\
\text { Analysis }\end{array}$ & $\begin{array}{l}\mathrm{t} \text {-value and Structural Equation } \\
\text { Coefficient } \\
\text { Coefficient of Determination }\left(\mathrm{R}^{2}\right)\end{array}$ & \multicolumn{2}{|c|}{$\begin{array}{l}\geq 1.96(\text { absolute value })=\text { significant } \\
\mathrm{R}^{2} \text { figure indicates that the latent variable is } \\
\text { exogenous } \\
\text { Explain the percentage of variance } \\
\text { Against endogenous latent variables } \\
\mathrm{R}^{2}<0.2=\text { weak } \\
\mathrm{R}^{2} \text { between } 0.2 \text { and } 0.5=\text { moderate } \\
\mathrm{R}^{2}>0.5=\text { strong } \\
(\text { Sridharan et al., 2012) }\end{array}$} \\
\hline
\end{tabular}

The model in this study is built to see how big the correlation between Activities and Perceived Ease of Use, the correlation betwen Activity and Perceived Usefulness, the correlation between Media and Perceived Ease of Use, the correlation between Perceived Ease of Use and Perceived Usefulness, the correlation between Perceived Usefulness and Behavioural Intention, the correlation between Behavioural Intention and Usage Behaviour, and see the indicators that reflect these components and their latent component correlations.

Table 4. Analysis of the suitability (goodness of fit test) of the overall model

\begin{tabular}{|c|c|c|c|}
\hline GOF & Cut off Value & $\begin{array}{l}\text { Value of } \\
\text { Research } \\
\text { Results }\end{array}$ & Notes \\
\hline Chi-square $\left(\chi^{2}\right)$ & Preferably small of Df & 352.34 & Good enough: fit \\
\hline Df & & 163 & Good enough: fit \\
\hline $\begin{array}{l}\text { Chi-square } \\
\left(\chi^{2}\right) / \mathrm{df}\end{array}$ & $\begin{array}{c}\leq \leq 3 \\
(2: 1 \text { (Tabachnik and Fidell, 2007) and } \\
3: 1(\text { Kline, 2005)) } \\
\end{array}$ & 2.161 & Good: good fit \\
\hline $\begin{array}{l}\text { Probability (P- } \\
\text { value) }\end{array}$ & $\geq 0.05$ & 0.12 & Good: good fit \\
\hline RMR & $\begin{array}{l}\text { A good model has a small RMR (Tabachnik } \\
\text { and Fidell, 2007), } \leq 0.05 \text { or } 0.08 \text { (Hair, 2007) }\end{array}$ & 0.0488 & Good: good fit \\
\hline RMSEA & $\leq 0.08$ & 0.072 & Good: good fit \\
\hline GFI & $\geq 0.90$ & 0.994 & Good: good fit \\
\hline AGFI & $\geq 0.90$ & 0.993 & Good: good fit \\
\hline CFI & $\geq 0.90$ & 1.000 & Good: good fit \\
\hline NFI & $\geq 0.90$ & 1.000 & Good: good fit \\
\hline NNFI & $\geq 0.90$ & 1.029 & Good: good fit \\
\hline RFI & $\geq 0.90$ & 1.000 & Good: good fit \\
\hline IFI & $\geq 0.90$ & 1.025 & Good: good fit \\
\hline
\end{tabular}

To find out whether a proposed measurement model is fit or not with the data, a measurement model suitability test is carried out. A measurement model can be called fit with data if the model can estimate the 
covariance matrix of the data. The fit size is indicated by the Chi-squared $\left(\chi^{2}\right) / \mathrm{df} \leq 3$. The processed data show that the value of Chi-squared $(\chi 2) / \mathrm{df}=2.16$. This means that the measurement model is fit (very good). Another determining factor is the measure of the Goodness of Fit (GOF) test such as the Comparative Fit Index (CFI) value is greater than 0.90 , the Probability (P-value) produced by the model is in the good category with a value of 0.12 $\geq 0.05$, RMSEA value is quite good / fit with a value of $0.072 \leq 0.08$. The overall model suitability criteria have been met, so that the model built in the study can be said to be good.

Based on Table 3, it is known that the correlation between components seen from the SLF and t-values for each component and indicator has met the requirements, so it can be said that the components of Activity, Media, Perceived Usefulness, Perceived Ease of Use, Behavioural Intentional and Usage Behavioural Intention have been valid, this is also supported by the correlation value for each component with a t-value $\geq 1.96$, which means that each component is significant. The overall model has good construct reliability by looking at the consistency measure of the CR (Construct Reliability) value and the size of the number of variant of VE (Variance Extracted) value of $98.7 \%$ and $50.1 \%$, where the $\mathrm{CR}$ and VE values have met the standard provisions or have been declared valid. Where $\mathrm{CR}$ is declared valid if the value is $>70 \%$ and $\mathrm{VE}$ is declared valid if the value is $>50 \%$.

Table 5. SLF value and overall model t-value

\begin{tabular}{|c|c|c|c|c|c|}
\hline Latent Variable & Indicator & $\begin{array}{l}\text { Coefficient / } \\
\text { SLF }(\lambda)\end{array}$ & $\begin{array}{l}\text { T-value } \\
(\geq 1.96) \\
\end{array}$ & Error Var & $\lambda^{2}$ \\
\hline \multicolumn{6}{|c|}{$\begin{array}{l}\text { Activity } \rightarrow \text { PEU }:(\mathrm{SLF}=0.50 \text { and } \mathrm{t}-\mathrm{value}=4.92) \\
\text { Activity } \rightarrow \text { PU }:(\mathrm{SLF}=0.55 \text { and } \mathrm{t}-\mathrm{value}=7.94)\end{array}$} \\
\hline \multirow{6}{*}{$\begin{array}{c}\mathrm{CR}=92.6 \% \\
\mathrm{VE}=68 \%\end{array}$} & Network & 0.64 & 18.91 & 0.59 & 0.41 \\
\hline & Regulation & 0.87 & 26.29 & 0.24 & 0.76 \\
\hline & Infrastructure & 0.89 & 25.87 & 0.21 & 0.79 \\
\hline & Political & 0.85 & 24.96 & 0.28 & 0.72 \\
\hline & Service Provider & 0.87 & 26.46 & 0.24 & 0.76 \\
\hline & Social & 0.8 & 23.57 & 0.36 & 0.64 \\
\hline \multicolumn{6}{|c|}{ Media $\rightarrow$ PEU (SLF $=0.28$ and t-value: 2.55 ) } \\
\hline \multirow{3}{*}{$\begin{array}{l}\mathrm{CR}=91.9 \% \\
\mathrm{VE}=79.3 \%\end{array}$} & Electronic Media & 0.93 & 20.67 & 0.14 & 0.86 \\
\hline & Social Media & 0.96 & 21.00 & 0.08 & 0.92 \\
\hline & Traditional Media & 0.77 & 18.48 & 0.41 & 0.59 \\
\hline \multicolumn{6}{|c|}{$\mathrm{PEU} \rightarrow \mathrm{PU}(\mathrm{SLF}=0.40$ and t-value: 4.79$)$} \\
\hline \multirow{4}{*}{$\begin{array}{l}\mathrm{CR}=91.9 \% \\
\mathrm{VE}=74.1 \%\end{array}$} & Product Value & 0.97 & 0.00 & 0.06 & 0.94 \\
\hline & Product Price & 0.79 & 16.52 & 0.38 & 0.62 \\
\hline & Product Discount & 0.88 & 17.35 & 0.23 & 0.77 \\
\hline & Product Delivery & 0.79 & 16.37 & 0.38 & 0.62 \\
\hline \multicolumn{6}{|c|}{$\mathrm{PU} \rightarrow \mathrm{BI}(\mathrm{SLF}=0.93$ and $\mathrm{t}$-value: 19.86$)$} \\
\hline \multirow{5}{*}{$\begin{array}{l}\mathrm{CR}=98.7 \% \\
\mathrm{VE}=93.8 \%\end{array}$} & Desire & 0.95 & 0.00 & 0.10 & 0.90 \\
\hline & Awareness & 0.97 & 19.46 & 0.06 & 0.94 \\
\hline & Ability & 0.99 & 19.63 & 0.02 & 0.98 \\
\hline & Knowledge & 0.93 & 19.06 & 0.14 & 0.86 \\
\hline & Usefulness & 1 & 19.66 & 0.00 & 1.00 \\
\hline \multicolumn{6}{|c|}{$\mathrm{BI} \rightarrow \mathrm{UB}(0.84$ and $\mathrm{t}$-value 11.87$)$} \\
\hline \multirow{2}{*}{$\begin{array}{l}\mathrm{CR}=75.9 \% \\
\mathrm{VE}=76 \%\end{array}$} & Behavioural Intention & 0.87 & 0.00 & 0.24 & 0.76 \\
\hline & Usage Behaviour & 1.06 & 0.00 & -0.12 & 1.12 \\
\hline \multicolumn{6}{|c|}{ CR overall model $98.7 \%$} \\
\hline & VE over & $.1 \%$ & & & \\
\hline
\end{tabular}

The following is a Path Diagram image consisting of components of Activity, Media, Perceived Usefulness, Perceived Ease of Use, Behavioural Intention, and Usage Behaviour. Based on Figure 3 and Figure 4 it can be seen 
the magnitude of the correlation between components and its significance.

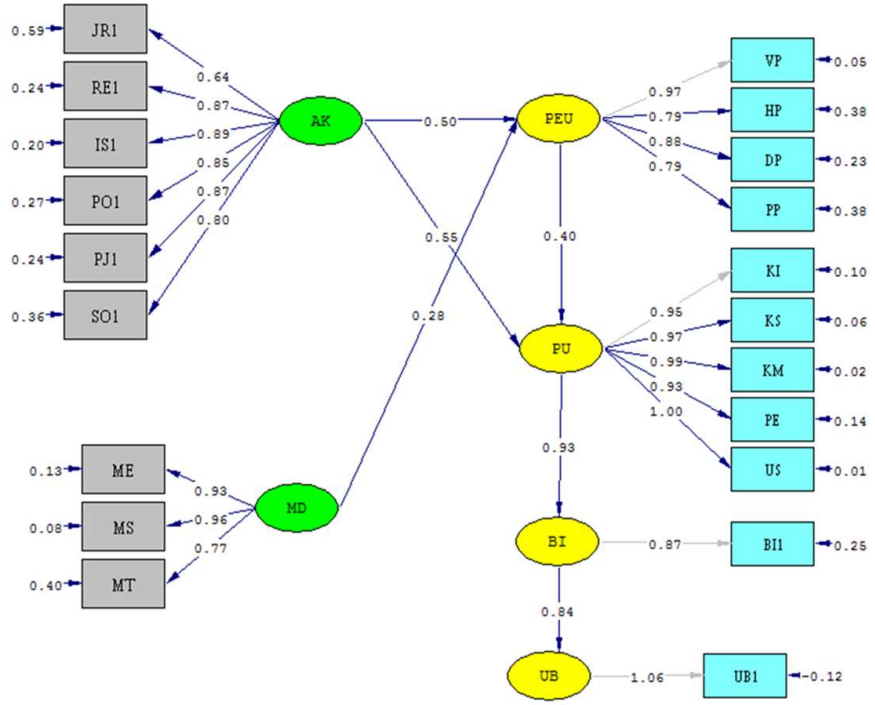

Chi-Square $=352.34, \mathrm{df}=163, \mathrm{P}=\mathrm{value}=0.12, \mathrm{RMSEA}=0.072$

Figure 3. Output standardized solution SEM Lisrel $8.801^{\text {st }}$ order model

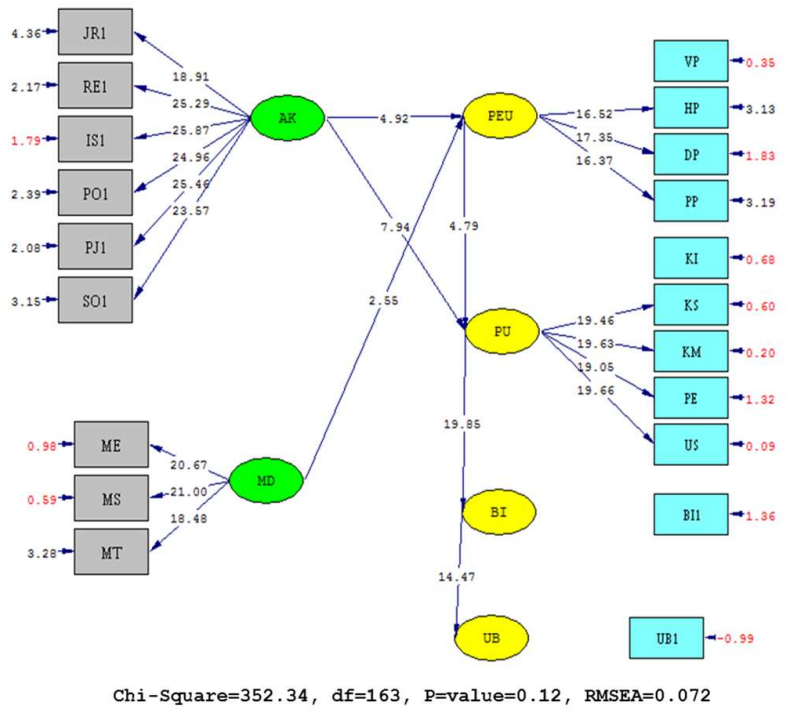

Figure 4. Output t-value SEM Lisrel $8.801^{\text {st }}$ order model

\subsubsection{Relationship Between Each Component}

\subsubsection{Relationship between Activities and Perceived Ease of Use}

Based on the results of the analysis, it is known that the component of Activities (AK) has a significant correlation with Perceived Ease of Use with direct correlation as evidenced by the t-value of $4.92>$ the $t$-tabel of 1.96. Thus, Hypothesis 1 (H1) is proven that the Activities (AK) have a significant correlation with Perceived Ease of Use. These results re in line with Susanto's (2016) research, which states that the Activities, especially social, have a positive and significant correlation to Perceived Ease of Use. In this study, it is stated that the greatest the number of users, it will correlate with the ease with which other users use a product, especially in the form of an application. In contrast to this study, Bachtiar (2014) states that the actvities do not have a significant correlation with the perceived ease of use of the product.

\subsubsection{Relationship between Activities and Perceived Usefulness}

The variable of Activities (AK) have a significant correlation with the Perceived Usefulness with the tvalue of $7.94>$ the t-tabel of 1.96. Thus, Hypothesis $2(\mathrm{H} 2)$ is proven. These results support the research conducted 
by Pratama (2014), where in his research it is known that the social, which is part of activities, has a positive and significant correlation to the Perceived Usefulness. This correlation means that the activities are correlated with the perceived usefulness and benefits. The social activities correlate with the perceptions of product needs. In contrast to the results of this study, according to Bachtiar (2014), stating that the Activities related to available TIK facilities do not have significant correlation with the Perceived Usefulness. This means that Bachtiar (2014) states that the activities do not correlate with the perceived usefulness or benefits of a product.

\subsubsection{Relationship between Media and Perceived Ease of Use}

Media (MD) has a significant correlation with the Perceived Ease of Use with a direct correlation with the $\mathrm{t}$-value of $2.55>$ the $\mathrm{t}$-tabel of 1.96 , then Hypothesis $3(\mathrm{H} 3)$ is proven. These results support the research conducted by Triatmaja (2019), where the research states the media, especially the social media, has a positive and significant correlation to the Perceived Ease of Use. This means that the use of media can help the respondents to provide a perception of the ease of use of the product. Lavenia, Iqbal, and Irawan (2018) also state that the internet media in general has a significant correlation with the perception of product usage satisfaction where the media can help to provide the respondents' needs for the perceived ease of use.

4.2.1.4 Relationship between Perceived Ease of Use and Perceived Usefulness

Perceived Ease of Use (PEU) has a significant correlation with Perceived Usefulness (PU) with the t-value of $4.79>$ the t-tabel of1.96, so Hypothesis 4 (H4) is proven. These results support the research conducted by Santoso B (2010) where in his research it is known that the perceived ease of use is positively correlated with the perceived usefulness, this correlation is based on the fact that the easier a system is used, the more the system is felt to be helpful.

These results are also in line with the research of Mandasari IA and Giantara IG (2017) which states that the perceived ease of use has a positive and significant correlation to the perceived usefulness, because the attitude of users of information systems is determined by the perceived usefulness and the perceived ease of use. Users will feel greater benefits if they feel the ease of using the information system.

\subsubsection{Relationship between Perceived Usefulness and Behavioral Intention}

Perceived Usefulness (PU) has a significant correlation with Behavioural Intention with a direct correlation with the t-value of $19.86>$ the t-tabel of 1.96, Hypothesis 5 (H5) is proven. These results support the research conducted by Hanggono AA, Handayani SR, and Susilo H (2015) where the research implies that there is a correlation between Perceived Usefulness and Behavioural Intention. So it can be interpreted that if Perceived Usefulness is high but there is an element of dislike in the user, it will decrease the correlation of Perceived Usefulness to Behavioural Intention.

\subsubsection{Relationship between Behavioral Intention and Usage Behaviour}

Behavioural Intention has a significant correlation to the Usage Behaviour with a direct correlation with the t-value of $11.87>$ the $\mathrm{t}$-tabel of 1.96 , so Hypothesis 6 (H6) is proven. These results support the research conducted by Setiadjie RP and Widodo T (2017) where in their research it is concluded that the use behavior variable is correlated with the behavioural intention. This is because the customer's intention to continue using the service can influence the customer to subscribe.

\subsubsection{Indicator Correlation}

The indicators that correlate to each component are based on the data of Standardized Loading Factor (SLF), the correlation between the indicators on the path diagram is as follows:

a. All indicators that correlate to the Activation component have a strong correlation with SLF values $>0.5$. The SLF values for each indicator are as follows: Infrastructure (0.89), Regulation (0.87), Service Provider (0.87), Political (0.85), Social Condition (0.8), and Network (0.64).

b. All indicators that correlate to the media component have a strong correlation with SLF values $>0.5$. The SLF values for each indicator are as follows: Social Media (0.96), Electronic Media (0.93) and Traditional Media (0.77).

c. All indicators that correlate to the Perceived Ease of Use component have a strong correlation with an SLF value $>0.5$. The SLF values for each indicator are as follows: Product Value (0.97), Product Discount (0.88), Product Price (0.79), and Product Delivery (0.79).

d. All indicators that correlate to the Perceived Usefulness have a strong correlation with an SLF value $>0.5$. The SLF values for each indicator are as follows: Ability (0.99), Awareness (0.97), Desire (0.95) and Knowledge (0.93).

\subsection{Policy Implications}

In the model that is built, it gives the meaning of the relationship between activities, media, benefits, 
convenience, intention and behavior towards the application of mobile money technology in rural communities. The Activities and Media Components affect the perception of the ease with which people use mobile money. When the people feel the convenience that is supported by activities, they will feel the benefits of this mobile money technology. The benefits that are felt will have an impact on the people's intentions and behaviour to use the mobile money in every daylife.

The dissemination process needs to be supported by the role of related institutions that have a correlation with indicators that influence the dissemmination process, among others:

a. Telecommunication Provider: Provision of 3G / 4G networks, the programs for providing smartphones and data packages that are affordable to rural communities,

b. Mobile Money Provider: Creating Value Mobile Money that suits the needs of rural communities, expanding services by increasing the number of merchants in rural communities, creating sweetener programs at attractive prices, delivering products that are easy to understand through the community with the support of communication media suitable for rural communities,

c. Local Government: Policy support for realizing economic digitization through the establishment of mobile money ecosystem, ease of licensing for telecommunication and mobile money providers, the application of mobile money for social assistance payments, PBB, regional taxes, recreation,

d. Bank Indonesia \& OJK: Disseminating and introducing the mobile money policy as a safe transaction tool,

e. Bank: Increasing the number of ATM and collaborating with the mobile money providers to increase the value of mobile money, savings and loans, and installment programs

\section{Conclusion}

\subsection{Conclusion}

The components of Activities, Media, Perceived Usefulness, Perceived Ease of Use, Behavioural Intention and Usage Behaviour have a strong correlation to the intention and willingness of rural communities in using and utilizing the mobile money in the rural communities,

a. Based on the SLF value, the two Indicators of each component that are strongly correlated are:

- Activities Component: Infrastructure and Regulation.

- Media Component: Social Media and Electronic Media.

- Perceived Ease of Use Component: Product Value and Product Discount.

- Perceived Usefulness Component: Ability and Awareness.

b. In planning the dissemination of the application of mobile money technology in rural communities must consider:

- Ease of gaining experience in using mobile money through: infrastructure readiness (cellular networks, smartphones, merchants), understanding regulations, increasing public capacity and awareness through community formation.

- Mobile money administrators must develop products that have added value for rural communities with attractive discount programs and are delivered on an ongoing basis through social media and electronic media, so that the rural community is continuously updated with information.

\subsection{Suggestion}

Telecommunication and mobile money service providers need to expand the reach of their target services to rural areas, so as to improve the welfare of rural communities. Service features need to be made according to the needs of rural communities, easy to understand and use and provide benefits and added value to the rural communities.

The availability of smartphones and cheap data packages that are affordable for rural communities through the installment program needs to be developed through a bundling program that collaborates between telecommunications providers, mobile money, distributors and local governments. To build a mobile money ecosystem, local government needs support through policies that are directly related to the use of mobile money as a means of payment for transactions managed by local governments. 


\section{References}

Abhay Upadhayaya. 2012. Electronic Commerce and E-wallet. India

Aleksandar. 2001. E money in transitional economies.

Anjum R. 2015. Design of Mobile Phone Services to Support Farmers in Developing Countries. Mater's Thesis. School of Computing Faculty of Science and Forestry University of Eastern Finland.

Bank Indonesia: Laporan Perekonomian Indonesia 2018.

Brannback, Malin.2003. Role of Ba in Knowledge - Creating Networks. Knowledge Management Research dan Practice 1, 28-38, R \&D Collaboration,

Brownson, PhD, Julie A. Jacobs, MPH, Rachel G. Tabak, PhD, Christine M. Hoehner, PhD, MSPH, and Katherine A. Stamatakis, PhD, MPH. Designing for Dissemination Among Public Health Researchers: Findings From a National Survey in the United States, Ross C.

Bachtiar A. 2014. Analisis Faktor-Faktor yang Mempengaruhi Tingkat Penerimaan Aplikasi E-Learning di Universitas Muhammadiyah Surabaya Menggunakan Modified Technology Acceptance Model [thesis]. Surabaya (ID): Institut Teknologi Sepuluh November Surabaya.

Christina t. Yuan, Ingrid M. neMbhard, aMY F. stern, John e. brush, Jr., Harlan M. KruMholz, and Elizabeth h. BradleY. 2010. Beyond Scientific Publication: Strategies for Disseminating Research Findings, Yale Center for Interdisciplinary Research on AIDS (CIRA), Blueprint for the Dissemination of EvidenceBased Practices in Health Care.

DailySocial.id: E money survey 2017

Deichmann U, Goyal A, Mishra D. 2016. Will Digital Technologies Transform Agriculture in Developing Countries? World Bank Grup: Policy Research Working Pages 7669.

Dube S. Togara T, Dube B. 2016. Agriculture Information Dissemination Mobile Application. In: Trimble J. 7th International Conference on Appropriate Technology: Sustainable Techmologies to Empower Communities - Bridging Theory with Practice: 2016 November 23-26; Victoria Falls, Zimbabwe. Zimbabwe (ZW): $28-41$.

E Campbell, R A Walsh, R Sanson-Fisher, S Burrows, E Stojanovski. 2006. A grup randomized trial of two methods for disseminating a smoking cessation programmer to public antenatal clinics: effects on patient

Erin P. Hambrick, Sonia L. Rubens, Eric M. Vernberg, Anne K. Jacobs, Rebecca M. Kanine. 2014. Towards Successful Dissemination of Psychological First Aid: A Study of Provider Training Preferences

Erizal Jamal, Maesti Mardiharini and Muhrizal Sarwani . 2008. Proses diseminasi pengelolaan tanaman dan sumber daya terpadu (PTT) Padi: suatu pembelajaran dan perspektif ke Depan.

Evan Buana. 2013. Analisis menggunakan soft system methodology studi penanggulangan Narkoba di Tanah Air. Universitas Indonesia.

Fernando Sousa, Gian Nicolay, Robert Home. Dissemination an Implementation of Agricultural Innovations Using Video on Mobile Phones in Mali.

GSM Association. 2018. The Mobile Economy 2018.

Hair Jr. JF, RE Anderson, RL Tatham, WC Black. 1998. Multivariate Data Analysis. Fith Edition. Prentice Hall International Inc.,New Jersey.

Hair Jr JF, Black WC, Babin BJ, Anderson RE, Thatam RL. 2006. Data Analysis Multivariate $6^{\text {th }}$ Edition. Upper Saddle River. NJ: Pearson Education, Inc.

Hanggono, A.A., Handayani, S.R., and Susilo, H. 2015. Analisis Atas Praktek TAM (Technology Acceptance Model) dalam Mendukung Bisnis Online dengan Memanfaatkan Jejaring Sosial Instagram. Journal of Administration Business (JAB), Vol. 26 No 1 September 2015.

Hornby, AS. 1974. Oxford Advanced Learner's Dictionary of Current English. London (UK): Oxford University Press.

Hox, JJ and Bechger, TM. 1998. An Introduction to Structural Equation Modeling. Family Science Review. 11: 354-373.

Jaworski, Bernard, J, Ajay K, Kohli. 1993. Market Orientation: Antecedents and Consequences. Journal of Marketing. 57.

Jiangping Wan, Qingjing Liu, Dejie Li, Hongbo Xu. 2010. Research on Knowledge Transfer Influencing Factors in Software Process Improvement.

Jia-Yin Qi, Yong-Pin Zhou, Wen-Jing Chen and Qi-Xing Qu J. 2012. Are customer satisfaction and customer loyalty drivers of customer lifetime value in mobile data services: a comparative cross-country study.

Karen Bankston. 2014. What's in Your Wallet Strategy.

Kepha Nyankora Getembe, Peterson Obara Magutu and Maxmillah Bituntu Muro. 2013. Electronic Money Transfer System and Business Process Management among Commercial Banks in Kenya.

Khalid, Osman. 2014. Efficient Message Dissemniation Framework for Diverse Wireless Networks.

Kihoma L. 2016. The Contribution of Mobile money Transfer in Marketing Agricultural Products of Women Involved in Agribusiness in Morogono Municipality Tanzania. Thesis. Haramaya University. 
Kurkeja, Ankur and Bidisha Chakrabarti. 2013. Agricultural Knowledge Management and Dissemination: Initiatives by Information and Communication Technology.

Lavenia BC, Iqbal M, Irawan A. 2018. Pengaruh Technology Acceptance Model (TAM) dan Electronic Word Of Mouth (EWOM) terhadap Kepuasan Pelanggan (Survei Pada Pelanggan Go-Jek di Kota Kediri) [journal]. Malang (ID): Faculty of Administrative Sciences, Universitas Brawijaya.

M Sonny Zulhuda and Ida Madieha Abdul Ghani Azmi Malaysia. 2011. Security Safeguards on e-Payment Systems in Malaysia: Analysis on the Payment Systems Act 2003.

M. Reichardt, C. Jürgens, U. Klo“ble, J. Hu“ ter, K. Moser. 2009. Dissemination of precision farming in Germany: acceptance, adoption, obstacles, knowledge transfer and training activities.

Mandasari IA and Giantara IG. 2017. Pengaruh Perceived Usefulness, Perceived Ease of Use, dan Kualitas Layanan terhadap Kepuasan untuk Membangun Loyalitas. E-Journal of Economics and Business, Universitas Udayana. 3637-3664.

Pratama BP. 2014. Faktor-faktor yang Mempengaruhi Penerimaan Sistem Pengadaan Secara Elektronik (SPSE): Studi Kasus Kementerian Keuangan [thesis]. Depok (ID): Fakultas Ilmu Komputer Universitas Indonesia.

Santoso B. 2010. Pengaruh Perceived Usefulness, Perceived Ease of Use, dan Perceived Enjoyment terhadap Penerimaan Teknologi Informasi (Studi Empirik di Kabupaten Sragen). Surakarta (ID): Universitas Sebelas Maret.

Setiadjie RP and Widodo T. 2017. Analisis Anteseden Behavioural Intention dan Pengaruhnya terhadap Use Behaviour pada Layanan Musik Online Berbasis Langganan di Indonesia. E-Proceeding of Management. 4(2).

Susanto J. 2016. Analisis Faktor-Faktor yang Mempengaruhi Adopsi Aplikasi GO-JEK Sebagai Penyedia Jasa Transportasi di Surabaya [journal]. Surabaya (ID): Universitas Ciputra.

SuharjoB, Suwarno. 2002. Linear Structural Relationship (LISREL) Teori dan Aplikasinya. Bogor: Department of Mathematics of FMIPA IPB.

Triatmaja MF. 2019. Pengaruh Penggunaan Media Sosial terhadap Keunggulan Bersaing dengan Menggunakan Pendekatan Technology Acceptance Model (TAM) untuk Meningkatkan Strategi Pemasaran Industri Batik di Kota Pekalongan [journal]. Pekalongan (ID): STIE Muhammadiyah Pekalongan.

Wijanto, S. 2008. Structural Equation Modeling dengan Lisrel 8.8. Yogyakarta (ID): Graha Ilmu. 